\title{
Fertilizer micro-dosing and harvesting time of indigenous leafy vegetables affect in vitro antioxidant activities
}

\author{
Modoukpè I. Djibril Moussa ${ }^{a^{*}}$, Adeola M. Alashi ${ }^{b}$, Carole N.A. Sossa-Vihotogbéc, \\ P.B. Irénikatché Akponikpèd, Mohamed N. Baco ${ }^{\mathrm{e}}$, André J. Djènontin ${ }^{\mathrm{d}}$, \\ Rotimi E. Aluko ${ }^{b}$ and Noël H. Akissoéa
}

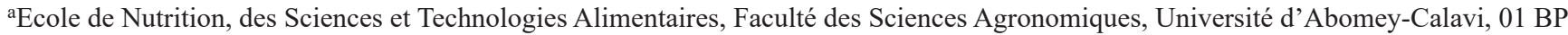
526, Cotonou, République du Bénin

bepartment of Food and Human Nutritional Sciences, University of Manitoba, Winnipeg, Manitoba, Canada R3T 2N2

'Département de Nutrition et Sciences Alimentaires, Faculté d'Agronomie, Université de Parakou, République du Bénin

${ }^{d}$ Laboratoire d'Hydraulique et de Modélisation Environnementale, Faculté d'Agronomie, Université de Parakou, 03 BP 351, Parakou,

République du Bénin

eLaboratoire Société-Environnement, Faculté d'Agronomie, Université de Parakou, BP 27, Parakou, République du Bénin

${ }^{*}$ Corresponding author: Modoukpè I. Djibril Moussa, Ecole de Nutrition, des Sciences et Technologies Alimentaires, Faculté des Sciences Agronomiques, Université d'Abomey-Calavi, 01 BP 526, Cotonou, Republic of Benin. Tel: (+229) 66679146; E-mail: dimayath@gmail.com DOI: $10.31665 / J F B .2019 .6189$
\end{abstract}

Received: April 19, 2019; Revised received \& accepted: June 28, 2019

Citation: Djibril Moussa, M.I., Alashi, A.M., Sossa-Vihotogbé, C.N.A., Akponikpè, P.B.I., Baco, M.N., Djènontin, A.J., Aluko, R.E., and Akissoé, N.H. (2019). Fertilizer micro-dosing and harvesting time of indigenous leafy vegetables affect in vitro antioxidant activities. J. Food Bioact. 6: 118-130.

\begin{abstract}
Plant nutrient management can influence the type and level of polyphenolic compounds within leafy vegetables. Therefore, we investigated the effects of fertilizer micro-dosing and harvest time on antioxidant activities of aqueous polyphenolic extracts from Amaranthus cruentus, Ocimum gratissimum and Solanum macrocarpon. Plants were cultivated using urea alone or combined with cattle manure for three staggered harvest periods. Polyphenolics profile (RP-HPLC), DPPH, hydroxyl and superoxide radical scavenging activities, ferric ion reducing power, ferrous ion chelation and inhibition of linoleic acid oxidation were determined. Polyphenolic contents of $A$. cruentus (caffeic acid, myricetin, quercetin and rutin) and $O$. gratissimum (catechin and gallic acid) as well as antioxidant activities of the vegetables extracts (except hydroxyl radical scavenging by $A$. cruentus) were fertilizer micro-dose and harvest timedependent. Thus, combination of both factors highlighted the screening of optimal farming conditions for these vegetables in order to get leaf extracts possessing higher polyphenolic contents and antioxidant activities.
\end{abstract}

Keywords: Fertilizer micro-dosing; Free radical scavenging; Indigenous leafy vegetables; Lipid oxidation; Water-soluble polyphenols.

\section{Introduction}

Free radicals and reactive oxygen species (ROS) are produced in the human body during biochemical and metabolic processes and contribute to a high prooxidant/antioxidant ratio, which is associated with high prevalence of oxidative stress-related diseases (HuiFang et al., 2018; Houston, 2010). All organisms are naturally equipped with antioxidant protection systems, which are able to prevent the harmful effects of ROS, though this endogenous protection system cannot adequately counteract oxidative stress (Houston, 2010). Thus, improvement of this endogenous protection system through the supply of additional (exogenous) natural antioxidant compounds from food systems may be beneficial (Oboh et al., 2016; Tavarini et al., 2015). Most natural antioxidants found in plant foods are polyphenolic compounds, which are divided into three main families (flavonoids, phenolic acids and tannins) and 
several sub-families according to degree of unsaturation, degree of oxidation of the oxygenated heterocycle, position and number of substituents (Guerrero et al., 2012; Irondi et al., 2016; Mathew et al., 2015). These chemical differences within the structure of polyphenolic compounds contribute to their antioxidant activity exerted by acting as hydrogen or electron donors, reducing agents, transition metal chelators and quenchers of ROS (Fasakin et al., 2011; Yehye et al., 2015).

Ability of polyphenolic compounds to act as donors of hydrogen atoms or electrons was demonstrated in the transformation of DPPH radical into its reduced form DPPH-H (Yehye et al., 2015). Their reducing properties are associated with ability to break the free radical chain by donating an electron, to form transition metal ions and to react with some precursors of peroxide to prevent peroxide formation (Fasakin et al., 2011). Transition metal ions such as $\mathrm{Fe}^{2+}$ and $\mathrm{Cu}^{2+}$ can interact with hydrogen peroxide to generate hydroxyl radicals through Fenton reactions (Yehye et al., 2015). Superoxide radical can initiate lipid peroxidation either directly or by Fenton reactions via formation of hydroxyl radical (Fasakin et al., 2011). Lipid peroxidation proceeds via radical-mediated abstraction of hydrogen atoms from methylene and accelerated by the presence of hydroxyl radical (Fasakin et al., 2011; Yehye et al., 2015). The chain reaction of lipid peroxidation generates a complex mixture of secondary breakdown products such as aldehydes, ketones and other potentially toxic substances (Fasakin et al., 2011; Yehye et al., 2015). Thus, inhibition of lipid peroxidation is an important indicator of the antioxidant activity.

Vegetables, including leafy vegetables, contribute to a balanced and healthy diet because of the quality of their phytochemicals (vitamins and polyphenols), which can exert various antioxidant activities (Oboh et al., 2016; Olarewaju et al., 2018; Tavarini et al., 2015). Consumption of indigenous vegetables is rooted in dietary habits of Africans with Amaranthus cruentus (Amaranthaceae), Ocimum gratissimum (Lamiaceae) and Solanum macrocarpon (Solanaceae) belonging to a class of nutritionally and medicinally beneficial leafy vegetables (Achigan-Dako et al., 2010). These leafy vegetables are grown in various ecological zones and are often harvested on staggered timing after maturity (Achigan-Dako et al., 2010). They are inexpensive and rich sources of nutrients such as minerals, vitamins, carotenoids and polyphenols (Vodouhe et al., 2012), although their nutrient profiles are affected by agronomic and environmental factors including soil type, water and nutrient supply, cultivation methods and harvest time (Brasileiro et al., 2015; Sossa-Vihotogbé et al., 2013a; Tavarini et al., 2015).

The intensification of agricultural production to increase crop productivity on limited arable land is important to guarantee food availability and the positive role of mineral fertilizers (reduction of soil nutrient mining) within such cropping system is undeniable (Bindraban et al., 2015). The efficient use of mineral fertilizers through their micro-dosing provides promising results considering crops productivity and farmers' income when used for cerealbased cropping systems in sub-Saharan West Africa (Adams et al., 2016; Tovihoudji et al., 2018). The fertilizer micro-dosing technology utilizes direct application of a small quantity of mineral fertilizer placed at an optimized depth and distance around the target crop either at planting time or a few weeks thereafter (Adams et al., 2016; Tovihoudji et al., 2018). Little is known about the impact of this technology on performance of other cropping systems especially indigenous leafy vegetables and on their potential health benefits. This study was undertaken to determine the effects of fertilizer micro-dosing and harvesting time on the antioxidant activities of the polyphenolic extracts from three indigenous leafy vegetables, Amaranthus cruentus (AC), Ocimum gratissimum (OG) and Solanum macrocarpon (SM).

\section{Materials and methods}

\subsection{Chemicals}

The following reagents were purchased from Sigma-Aldrich (St Louis, Missouri, USA): 1,1-diphenyl-2-picryl-hydrazyl (DPPH); 1,10 phenanthroline; 2,4,6-tri(2-pyridyl)-S-triazine 1,1-diphenyl2-picrylhydrazyl (TPTZ); 3-(2-pyridyl)-5,6-bis (4-phenyl-sulfonic acid)-1,2,4-triazine (ferrozine); caffeic acid; catechin; ferrous sulphate $\left(\mathrm{FeSO}_{4}\right)$; gallic acid; hydrogen peroxide $\left(\mathrm{H}_{2} \mathrm{O}_{2}\right)$; linoleic acid; myricetin; potassium acetate $\left(\mathrm{CH}_{3} \mathrm{CO}_{2} \mathrm{~K}\right)$; pyrogallol; quercetin and rutin. Folin-Ciocalteu reagent, ethanol, hydrochloric acid $(\mathrm{HCl})$ and methanol were purchased from Fisher Scientific (Oakville, Ontario, Canada). All chemicals used were of analytical grade.

\subsection{Plant material}

Leafy vegetables were cultivated between January and June 2016 in experimental farm of the Northern Center of National Agricultural Research Institute (NARI) in Republic of Benin $\left(9^{\circ} 57^{\prime} \mathrm{N}\right.$, $2^{\circ} 43^{\prime} \mathrm{E}$ and $358 \mathrm{~m}$ a.s.1.; Ina village, Bembereke district). Vegetables were grown under fertilizer micro-dosing technology using urea alone $(80 \mathrm{~kg} / \mathrm{ha}$ coded D80) or combined $(0,20,40$ and $60 \mathrm{~kg} /$ ha, respectively coded D0, D20, D40 and D60) with cattle manure ( $5 \mathrm{t} / \mathrm{ha}$ ), in a randomized complete block design with four replications. Seeds were bought from NARI and grown in nurseries for four (AC) or six (OG and SM) weeks. Cattle manure was applied to experimental plot units $(6 \mathrm{~m} \times 1 \mathrm{~m})$ one week before transplanting while urea was applied immediately after transplanting.

\subsection{Sampling}

Harvests of each vegetable were staggered three times (H1, H2 and $\mathrm{H} 3$ ) and at regular intervals: 4-6-8 (AC), 6-10-14 (SM) and 8-12-16 (OG) weeks after transplanting. Vegetables were collected by cutting plants at a height of $10 \mathrm{~cm}$ above soil level excluding plants located at border lines of experimental units. The four replicates of the same treatment were bulked together to form a homogeneous sample, bagged, labelled and transported fresh with ice to laboratory. Sample were labeled by combining fertilizer micro-dose and harvest order (D0H1, D0H2, D0H3, D20H1, D20H2，D20H3，D40H1，D40H2，D40H3，D60H1，D60H2, $\mathrm{D} 60 \mathrm{H} 3, \mathrm{D} 80 \mathrm{H} 1, \mathrm{D} 80 \mathrm{H} 2$ and D80H3) for each vegetable species. Edible leaves were washed and drained before being oven-dried at $60{ }^{\circ} \mathrm{C}$ using a Memmert UN450 oven (Memmert GmbH + Co. $\mathrm{KG}$, Schwabach, Germany), for a minimum of $24 \mathrm{~h}$, until leaves had a constant weight. Dried leaves were ground using a Cuisinart Grinder (Model DCG-12 BCC, Cuisinart, Woodbridge, Ontario, Canada) and leaf powders were stored at $-20{ }^{\circ} \mathrm{C}$ before analysis.

\subsection{Polyphenol extraction}

Polyphenols were extracted from the leaf powders according to Djibril-Moussa et al. (2019) method using double deionized water (DDW) at 1:20 ratio (leaf powder to DDW). The mixture was stirred for $2 \mathrm{~h}$ at $60{ }^{\circ} \mathrm{C}$ on a IKA ${ }^{\circledR} \mathrm{C}-\mathrm{MAG}$ HS hotplate magnetic stirrer coupled with IKA ${ }^{\circledR}$ ETS-D5 temperature controller $($ IKA $\AA$, Wilmington, North Carolina, USA). Afterwards, the mixture was centrifuged for $30 \mathrm{~min}\left(5000 \times \mathrm{g}\right.$ at $\left.4{ }^{\circ} \mathrm{C}\right)$ using a Beckman Allegra $6 \mathrm{R}$ refrigerated centrifuge (Beckman Coulter Inc, Mississauga, 
Ontario, Canada). After centrifugation, the supernatant was decanted and filtered through cheesecloth. The filtrate was collected in a container while retained solids were combined with the precipitate and dispersed in another $200 \mathrm{~mL}$ of DDW. The extraction process was repeated as above and both filtrates were pooled, concentrated under vacuum at $60{ }^{\circ} \mathrm{C}$ using a Hei-VAP-Core rotary evaporator (Heidolph, Schwabach, Germany). The concentrated extracts were freeze-dried at $-80^{\circ} \mathrm{C}$ using a VirTis GPFD 24DX48 freeze dryer (SPScientific, Stone Ridge, New York, USA) to produce the aqueous polyphenolic extracts.

\subsection{Total phenolics content (TPC)}

TPC of the aqueous extracts was determined according to DjibrilMoussa et al. (2019) method. Aqueous extracts $(0.5 \mathrm{mg} / \mathrm{mL})$ and gallic acid $(25-300 \mu \mathrm{g} / \mathrm{mL})$ were separately dissolved in aqueous methanol $(50 \%, \mathrm{v} / \mathrm{v})$. A $250 \mu \mathrm{L}$ aliquot of the methanolic solutions was mixed with $250 \mu \mathrm{L}$ of Folin Ciocalteu reagent. The mixture was allowed to stand for $5 \mathrm{~min}$ before $500 \mu \mathrm{L}$ of $\mathrm{NaCO}_{3}(10 \%$, w/v) and $4 \mathrm{~mL}$ of DDW were added. Thereafter, the reaction mixture was thoroughly mixed and allowed to stand in the dark for $1 \mathrm{~h}$ at $25^{\circ} \mathrm{C}$. After $1 \mathrm{~h}$, absorbance was measured at $725 \mathrm{~nm}$ using a UV-Visible spectrophotometer (Ultrospec 4300 pro, Biochrom, Cambourne, Cambridge, England) coupled with SWIFT II instrument control data analysis software. TPC was calculated using regression equation from standard curve of gallic acid $\left(y=0.0039 x-0.096 ; R^{2}=0.9952\right)$ and expressed as gallic acid equivalent (GAE $\mathrm{mg} / \mathrm{g}$ of dry mass).

\subsection{Total flavonoids content (TFC)}

TFC of the aqueous extracts was determined according to DjibrilMoussa et al. (2019) method. Samples $(0.5 \mathrm{mg} / \mathrm{mL})$ were dissolved in DDW while rutin $(25-600 \mu \mathrm{g} / \mathrm{mL})$ was dissolved in methanol (99.9\%). A $100 \mu \mathrm{L}$ aliquot of sample was mixed with $300 \mu \mathrm{L}$ of dilution solvent, $20 \mu \mathrm{L}$ of $10 \%$ (w/v) $\mathrm{AlCl}_{3}, 20 \mu \mathrm{L}$ of $1 \mathrm{M} \mathrm{CH}_{3} \mathrm{CO}_{2} \mathrm{~K}$ and $560 \mu \mathrm{L}$ of DDW. The mixture was thoroughly shaken and allowed to stand for $30 \mathrm{~min}$ at room temperature. Absorbance of reaction was measured at $415 \mathrm{~nm}$ using the Power wave XS2 spectrophotometer (BioTek Instruments, Inc., Winooski, Vermont, USA) coupled with Gen5 2.04 data analysis software. TFC was calculated using regression equation from standard curve of rutin $\left(y=0.0017 x-0.0145 ; R^{2}=0.9976\right)$ and expressed as rutin equivalent (RE $\mathrm{mg} / \mathrm{g}$ of dry mass).

\subsection{Profile of main polyphenolic compounds}

Polyphenolic compounds were identified and quantified according to Olarewaju et al. (2018) method with slight modifications. This method used a reversed-phase high-performance liquid chromatography system and was performed with a Varian 900-LC series system (Agilent Technologies, Santa Clara, California, USA) fitted with a $\mathrm{C} 18$ analytical column $(250 \times 4.6 \mathrm{~mm}, 5 \mu \mathrm{m})$ (Phenomenex Inc., Torrance, California, USA) pre-heated to $30{ }^{\circ} \mathrm{C}$. Polyphenolic extracts $(10 \mathrm{mg} / \mathrm{mL})$ were dissolved in DDW containing $1 \%$ acetic acid (mobile phase A) while standards (caffeic acid, catechin, gallic acid, myricetin, quercetin and rutin) were dissolved $(0.5-2 \mathrm{mg} / \mathrm{mL})$ in ethanol. Samples were incubated at room temperature for $1 \mathrm{~h}$ and filtered through $0.22 \mu \mathrm{m}$ discs. A $20 \mu \mathrm{L}$ aliquot of sample filtrate was injected into the column and solvents used were $1 \%$ acetic acid in DDW (mobile phase A) and methanol (mobile phase B). Elution was set at a flow rate of $1 \mathrm{~mL} / \mathrm{min}$ over $75 \mathrm{~min}$ with the following gradients: 95\% A and 5\% B for $35 \mathrm{~min} ; 80 \% \mathrm{~A}$ and 20\% B for 15 min; $40 \% \mathrm{~A}$ and $60 \% \mathrm{~B}$ for $10 \mathrm{~min}$ and $70 \% \mathrm{~A}$ and $30 \% \mathrm{~B}$ for 15 min. Polyphenolic compounds were detected using UV detectors set at wavelengths of 280 and $320 \mathrm{~nm}$. Chromatographic peaks were identified by comparing retention time of polyphenolic compounds from leaf extracts with those of standards. Quantification of compounds was made by integrating peaks areas using calibration curve generated from a linear plot of elution time versus peak area for each standard. Results were expressed as $\mathrm{mg} / \mathrm{g}$ of dried leaf extracts.

\subsection{Determination of antioxidant activities}

Six assays, each performed in triplicate, were used to determine antioxidant activity of polyphenolic extracts in comparison to blank (replacing samples by dilution solvent). DPPH radical scavenging activity (DPPH-RSA), hydroxyl radical scavenging activity (HRSA), superoxide radical scavenging activity (SRSA), ferric ion reducing antioxidant power (FRAP), ferrous ion chelation (FIC) and inhibition of linoleic acid oxidation (ILAO) were assayed following methods described by Fasakin et al. (2011), with slight modifications. Absorbance of blank $\left(\mathrm{A}_{\text {blank }}\right)$ and samples $\left(\mathrm{A}_{\text {sample }}\right)$ were measured using a spectrophotometer Power wave XS2 coupled with Gen5 2.04 data analysis software and antioxidant activity was calculated as follows:

$$
\text { Antioxidant activity }(\%)=\frac{A_{\text {blank }}-A_{\text {sample }}}{A_{\text {blank }}} \times 100
$$

\subsubsection{DPPH radical scavenging activity (DPPH-RSA)}

Aqueous extracts $(0.05-0.35 \mathrm{mg} / \mathrm{mL})$ were dissolved in $0.1 \mathrm{M}$ sodium phosphate buffer ( $\mathrm{pH}$ 7.0) containing 1\% Triton X-100. A 100 $\mu \mathrm{L}$ aliquot of sample was mixed with $100 \mu \mathrm{L}$ of DPPH in methanol $(100 \mu \mathrm{M})$ into 96-well plate and incubated under dark conditions, at room temperature for $30 \mathrm{~min}$. Absorbance of blank and samples were measured at $517 \mathrm{~nm}$ and DPPH-RSA was calculated.

\subsubsection{Hydroxyl radical scavenging activity (HRSA)}

Aqueous extracts $(2.5$ and $5.0 \mu \mathrm{g} / \mathrm{mL}$ for $\mathrm{AC}$ and $\mathrm{SM}, 1.0$ and 1.5 $\mathrm{mg} / \mathrm{mL}$ for $\mathrm{OG}$ ) were dissolved in $0.1 \mathrm{M}$ phosphate buffer $(\mathrm{pH}$ 7.4). A $50 \mu \mathrm{L}$ aliquot of sample was directly mixed into a clear bottom 96 -well plate with $50 \mu \mathrm{L}$ of 1,10 -phenanthroline $(3 \mathrm{mM})$, $50 \mu \mathrm{L}$ of $\mathrm{FeSO}_{4}(3 \mathrm{mM})$ and $50 \mu \mathrm{L}$ of $\mathrm{H}_{2} \mathrm{O}_{2}(0.01 \%)$. Absorbance of this mixture was read over $1 \mathrm{~h}$ (at $10 \mathrm{~min}$ intervals), at $37^{\circ} \mathrm{C}$ and $536 \mathrm{~nm}$. Kinetics of reaction rates of blank and samples were calculated over the time period and used to determine HRSA.

\subsubsection{Superoxide radical scavenging activity (SRSA)}

Aqueous extracts $(2.5$ and $5.0 \mu \mathrm{g} / \mathrm{mL}$ for $\mathrm{AC}$ and $\mathrm{SM}, 1.0$ and 1.5 $\mathrm{mg} / \mathrm{mL}$ for $\mathrm{OG})$ were dissolved in $50 \mathrm{mM}$ Tris- $\mathrm{HCl}$ buffer $(\mathrm{pH}$ 8.3) containing $1 \mathrm{mM}$ EDTA. A $80 \mu \mathrm{L}$ aliquot of hydrated aqueous extracts was mixed with $80 \mu \mathrm{L}$ of $50 \mathrm{mM}$ Tris- $\mathrm{HCl}$ buffer ( $\mathrm{pH} 8.3$ ) containing $1 \mathrm{mM}$ EDTA directly into a clear bottom 96-well plate. Pyrogallol $(1.5 \mathrm{mM})$ dissolved in $\mathrm{HCl}(10 \mathrm{mM})$ and $40 \mu \mathrm{L}$ was added to each well. Absorbance of this mixture was determined immediately at $1 \mathrm{~min}$ interval for $4 \mathrm{~min}$, at $25^{\circ} \mathrm{C}$ and $420 \mathrm{~nm}$. Kinetics of reaction rates of blank and samples were calculated over reading period and used to determine SRSA. 


\subsubsection{Ferric ion reducing antioxidant power (FRAP)}

Aqueous extracts $(0.5 \mathrm{mg} / \mathrm{mL})$ and $\mathrm{FeSO}_{4}(0.0625-1 \mu \mathrm{M})$ were dissolved in DDW. A $40 \mu \mathrm{L}$ aliquot of sample was pipetted into a clear bottom 96-well plate with $200 \mu \mathrm{L}$ of FRAP reagent $(100 \mathrm{~mL}$ of $0.3 \mathrm{M}$ acetate buffer ( $\mathrm{pH} 3.6), 20 \mathrm{ml}$ of TPTZ $(10 \mathrm{mM})$ in $\mathrm{HCl}$ $(40 \mathrm{mM})$ and $20 \mathrm{~mL}$ of $\left.\mathrm{FeCl}_{3}\right)$. Absorbance was measured at 593 $\mathrm{nm}$ and FRAP (expressed as $\mathrm{mM} \mathrm{Fe} \mathrm{F}^{2+} / \mathrm{mg}$ of dry mass) was calculated using regression equation from standard curve of $\mathrm{FeSO}_{4}(\mathrm{y}=$ $\left.2.1463 \mathrm{x}+0.0971 ; \mathrm{R}^{2}=0.9999\right)$.

\subsubsection{Ferrous ion chelation (FIC)}

Aqueous extracts $(0.2-0.7 \mathrm{mg} / \mathrm{mL})$ were dissolved in DDW. A $1 \mathrm{~mL}$ aliquot of sample was mixed with $25 \mu \mathrm{L}$ of $2 \mathrm{mM} \mathrm{FeCl}_{2}$ and $925 \mu \mathrm{L}$ of dilution solvent. A $50 \mu \mathrm{L}$ aliquot of $5 \mathrm{mM}$ Ferrozine solution was added and mixed thoroughly. The mixture was allowed to stand at room temperature for $10 \mathrm{~min}$ before a $200 \mu \mathrm{L}$ aliquot was pipetted into a clear bottom 96-well plate. Absorbance of blank and samples were read immediately at $562 \mathrm{~nm}$ and FIC was calculated.

\subsubsection{Inhibition of linoleic acid oxidation (ILAO)}

Aqueous extracts $(0.25$ and $0.50 \mathrm{mg} / \mathrm{mL})$ were dissolved in $5 \mathrm{~mL}$ of $0.1 \mathrm{M}$ sodium phosphate buffer (pH 7.0). A $5 \mathrm{~mL}$ aliquot of 50 $\mathrm{mM}$ linoleic acid dissolved in $99.5 \%$ ethanol was added to samples. The mixture was incubated at $60{ }^{\circ} \mathrm{C}$ in the dark over a period of 7 days and at $24 \mathrm{~h}$ intervals, $100 \mu \mathrm{L}$ was taken and mixed with $4.7 \mathrm{~mL}$ of aqueous ethanol (75\%), $100 \mu \mathrm{L}$ of ammonium thiocyanate $(30 \%)$ and $100 \mu \mathrm{L}$ of $\mathrm{FeCl}_{2}(0.02 \mathrm{M})$ dissolved in $\mathrm{HCl}(1 \mathrm{M})$. The resultant mixture was incubated for $3 \mathrm{~min}$ at room temperature followed by transfer of $200 \mu \mathrm{L}$ into a clear bottom 96 -well plate. Absorbance of blank and samples were measured at $500 \mathrm{~nm}$ and used to calculate ILAO.

\subsection{Statistical analysis}

Effective concentration of samples required to reduce free radical activities by $50 \%\left(\mathrm{EC}_{50}\right)$ was calculated using non-linear regression on a Prism 6 software (GraphPad Corp., La Jolla, USA). The $\mathrm{EC}_{50}$ is inversely related to effective activity and was not calculated when activity did not exceed $50 \%$ at highest concentration tested. Analysis of variance (ANOVA) on repeated measures was performed using R software version 3.1.0 (The R Foundation for Statistical Computing, Vienna, Austria) to determine effect of fertilizer microdose and harvest time on polyphenolic compounds and antioxidant activities of each vegetable species. Means were separated using Duncan's test. Correlations between polyphenolic compounds and antioxidant activities were determined by Pearson's test and linear regression analysis was performed on the most strongly correlated variables using Prism 6. Significance was set at $\mathrm{p}<0.05$.

\section{Results}

\subsection{Variability of polyphenolic compounds in leafy vegetables}

Typical chromatograms of polyphenolic compounds obtained for each vegetable species are presented in Figure 1, showing a variety of compounds comprising some identified and unidentified peaks, with differences between vegetable species. Quantification of identified compounds revealed significant differences between species: OG had higher contents of caffeic $(23.6 \mathrm{mg} / \mathrm{g})$ and gallic $(9.3 \mathrm{mg} / \mathrm{g})$ acids when compared to $\mathrm{AC}(8.3 \mathrm{mg} / \mathrm{g}$ and $6.7 \mathrm{mg} / \mathrm{g}$, respectively) and SM (3.6 mg/g and $7.8 \mathrm{mg} / \mathrm{g}$, respectively). Levels of catechin observed with AC $(2.7 \mathrm{mg} / \mathrm{g})$ and $\mathrm{OG}(2.6 \mathrm{mg} / \mathrm{g})$ were higher than that of SM $(<0.1 \mathrm{mg} / \mathrm{g})$. Myricetin contents in $\mathrm{SM}(34.8 \mathrm{mg} / \mathrm{g})$ and $\mathrm{AC}(22.6 \mathrm{mg} / \mathrm{g})$ were higher than that of $\mathrm{OG}$ $(4.5 \mathrm{mg} / \mathrm{g})$. Higher contents of quercetin $(52.4 \mathrm{mg} / \mathrm{g})$ and rutin (23.4 mg/g) were found in AC in comparison to OG $(13.9 \mathrm{mg} / \mathrm{g}$ and $6.5 \mathrm{mg} / \mathrm{g}$, respectively) and SM $(0.1 \mathrm{mg} / \mathrm{g}$ and $12.4 \mathrm{mg} / \mathrm{g}$, respectively).

\subsection{Effect of fertilizer micro-dose and harvest time on polyphe- nolic compounds}

ANOVA indicated significant interaction effects of fertilizer micro-dose and harvest time on some polyphenolic compounds in $\mathrm{AC}$ and $\mathrm{OG}$ (Table 1): caffeic acid $(\mathrm{p}=0.01)$, myricetin $(\mathrm{p}=0.02)$, quercetin $(p=0.03)$ and rutin $(p=0.03)$ contents of AC and catechin $(p=0.04)$, gallic acid $(p=0.01)$ and rutin $(p=0.03)$ contents of OG, thus suggesting the contents of these compounds may be related to fertilizer micro-dose and harvest time. Accordingly, the highest quercetin $(52.4 \pm 4.5 \mathrm{mg} / \mathrm{g})$ and rutin $(23.4 \pm 1.2 \mathrm{mg} / \mathrm{g})$ contents in AC were found in D20H1 and D20H2 while D20H3 had the lowest content $(<0.1 \mathrm{mg} / \mathrm{g})$. Likewise, gallic acid $(9.3 \pm$ $0.0 \mathrm{mg} / \mathrm{g})$ and rutin $(6.5 \pm 0.2 \mathrm{mg} / \mathrm{g})$ contents in $\mathrm{OG}$ were high in $\mathrm{D} 80 \mathrm{H} 1$ and $\mathrm{D} 80 \mathrm{H} 2$, respectively while for D80, the lowest contents $(<0.1 \mathrm{mg} / \mathrm{g})$ were respectively found at third $(<0.1 \mathrm{mg} / \mathrm{g})$ and first $(0.3 \pm 0.0 \mathrm{mg} / \mathrm{g})$ harvests. Higher caffeic acid content of $\mathrm{AC}(8.3 \pm 1.0 \mathrm{mg} / \mathrm{g})$ and catechin content of $\mathrm{OG}(2.6 \pm 0.3 \mathrm{mg} / \mathrm{g})$ were, respectively observed with $\mathrm{D} 0 \mathrm{H} 3$ and $\mathrm{D} 0 \mathrm{H} 1$ whereas with D0, the lowest contents $(<0.1 \mathrm{mg} / \mathrm{g}$ ) were obtained at first (caffeic acid) and second (catechin) harvests.

As far as fertilizer application is concerned, quantitative variations were observed within vegetable species with neither upward nor downward trend when increasing fertilizer micro-doses (Figure 2); similar trend was observed with harvest time. Gallic acid content of AC was significantly affected by fertilizer micro-dose $(p=0.02)$ and harvest time $(p=0.01)$ with the highest content found for AC grown with D0 and for leaves collected at second harvest (Table 1). Harvest time had significant effects on caffeic acid $(p=0.03)$, myricetin $(p=0.04)$ and quercetin $(p=0.03)$ contents of OG (Table 1), resulting in the highest contents at second harvest, except for caffeic acid that was higher at third harvest of OG.

Regarding SM, no significant effect of interaction of both factors was evidenced on identified polyphenolics although fertilizer micro-dose significantly affected its rutin content $(\mathrm{p}=0.02)$, with D60 giving significantly higher rutin content (Table 1). In regards to harvest time, polyphenolics had various behaviour: caffeic acid and rutin contents increased with harvesting time while the highest catechin and gallic acid contents were obtained at first harvest.

\subsection{Effect of fertilizer micro-dose and harvest time on antioxi- dant activities}

\subsubsection{DPPH radical scavenging activity (DPPH-RSA)}

The $\mathrm{EC}_{50}$ from DPPH-RSA varied in the range of $0.1-1.3 \mathrm{mg} /$ $\mathrm{mL}$ : $\mathrm{AC}(0.6-1.3 \mathrm{mg} / \mathrm{mL}), \mathrm{OG}(0.2-0.9 \mathrm{mg} / \mathrm{mL})$ and $\mathrm{SM}(0.1-0.7$ 

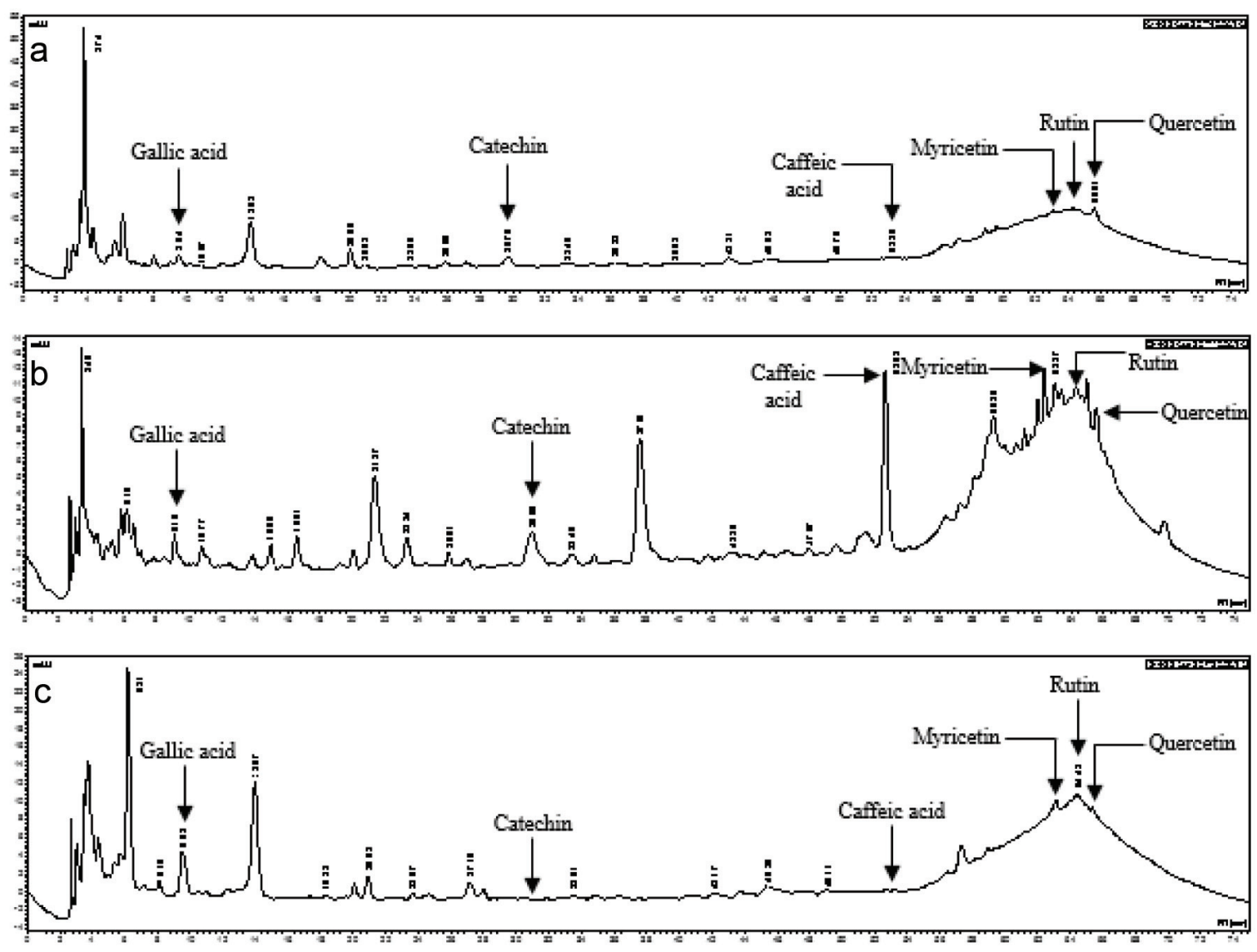

Figure 1. Chromatograms of polyphenolics compounds from Amaranthus cruentus (a), Ocimum gratissimum (b) and Solanum macrocarpon (c) produced with D60 and collected at first harvesting time.

Table 1. Effect of fertilizer dose (FD) and harvest time (HT) on polyphenols contents and antioxidant activities of vegetables species

\begin{tabular}{|c|c|c|c|c|c|c|c|c|c|c|}
\hline \multirow{2}{*}{ Variables } & & \multicolumn{3}{|c|}{ Amaranthus cruentus } & \multicolumn{3}{|c|}{ Ocimum gratissimum } & \multicolumn{3}{|c|}{ Solanum macrocarpon } \\
\hline & & FD & HT & FDxHT & FD & HT & FDxHT & FD & HT & FDxHT \\
\hline \multirow{6}{*}{$\begin{array}{l}\text { Polyphenolic } \\
\text { compounds }\end{array}$} & Caffeic acid ${ }^{1}$ & $883^{a^{*}}$ & $430^{*}$ & $2014^{*}$ & 16 & $416^{*}$ & 56 & 41 & $173^{*}$ & 141 \\
\hline & Catechin $^{1}$ & 81 & 85 & 12 & $162^{*}$ & 56 & $217^{*}$ & 55 & $297^{*}$ & 49 \\
\hline & Gallic acid ${ }^{1}$ & $1172^{*}$ & $2144^{*}$ & 115 & $912^{*}$ & $1019^{*}$ & $2802^{*}$ & 154 & $1052^{*}$ & 129 \\
\hline & Myricetin $^{1}$ & 138 & $40498^{* *}$ & $1096^{*}$ & 41 & $210^{*}$ & 64 & 19 & 3 & 31 \\
\hline & Quercetin $^{1}$ & $782^{*}$ & $456^{*}$ & $514^{*}$ & 2 & $561^{*}$ & 49 & 19 & 9 & 42 \\
\hline & Rutin $^{1}$ & $2402^{*}$ & $2279^{*}$ & $524^{*}$ & $2377^{*}$ & $1351^{*}$ & $345^{*}$ & $1639^{*}$ & $458^{*}$ & 82 \\
\hline \multirow{6}{*}{$\begin{array}{l}\text { Antioxidant } \\
\text { activities }\end{array}$} & DPPH-RSA ${ }^{2}$ & $9^{*}$ & $80^{* *}$ & $20^{*}$ & $778^{* * *}$ & $2051^{* * *}$ & $113^{* * *}$ & $18^{* *}$ & $6340^{* * *}$ & $90^{* *}$ \\
\hline & $\mathrm{HRSA}^{3 \mathrm{~b}}$ & $6^{c}$ & $110^{* * c}$ & $6^{c}$ & $247^{* * *}$ & $5519^{* * *}$ & $2240^{* * *}$ & $159^{* * *}$ & $1078^{* *}$ & $94^{* *}$ \\
\hline & $\mathrm{SRSA}^{3 \mathrm{~b}}$ & $93^{* *}$ & $58^{* *}$ & $85^{* *}$ & $191^{* *}$ & $389^{* *}$ & $54^{* *}$ & $40^{* *}$ & $201^{* * *}$ & $80^{* *}$ \\
\hline & FRAP 4 & $1583^{* * *}$ & $1401^{* *}$ & $533^{* * *}$ & $659^{* * *}$ & $210659^{* * *}$ & $4331^{* * *}$ & $379^{* *}$ & $14578^{* * *}$ & $1559^{* * *}$ \\
\hline & $\mathrm{FIC}^{2}$ & $3503^{* * *}$ & $81280^{* * *}$ & $547^{* * *}$ & $1906^{* * *}$ & $15228^{* * *}$ & $330^{* * *}$ & 7 & $502^{* * *}$ & $10^{*}$ \\
\hline & $\mathrm{ILAO}^{3 \mathrm{~d}}$ & $5651^{* * *} \mathrm{e}$ & $45228^{* * *} \mathrm{e}$ & $5126^{* * *} \mathrm{e}$ & $468^{* * *}$ & $2389^{* * *}$ & $576^{* * *}$ & $4021^{* * *}$ & $4055^{* * *}$ & $4308^{* * *}$ \\
\hline
\end{tabular}

Units: ${ }^{1} \mathrm{mg} / \mathrm{g} ;{ }^{2} \mathrm{EC}_{50}, \mathrm{mg} / \mathrm{mL} ;{ }^{3} \% ;{ }^{4} \mathrm{mM} \mathrm{Fe}{ }^{2+} / \mathrm{mg}$. Abbreviations: DPPH-RSA: DPPH radical scavenging activity; HRSA: hydroxyl radical scavenging activity; SRSA: superoxide radical scavenging activity; FRAP: ferric ions reducing antioxidant power; FIC: ferrous ions chelation; ILAO: inhibition of linoleic acid oxidation. ${ }^{a}$-value. ${ }^{b}$ Data from highest concentration tested $\left(5 \mu \mathrm{g} / \mathrm{mL}\right.$ for $A$. cruentus and S. macrocarpon and $1.5 \mathrm{mg} / \mathrm{mL}$ for $O$. gratissimum). ${ }^{\circ}$ Data used were those from the first two harvests of D0, D20, D40 and D60. ${ }^{\mathrm{d}} \mathrm{Ddata}$ from lowest concentration tested $(0.25 \mathrm{mg} / \mathrm{mL})$ at highest inhibition day (day 4). ${ }^{e}$ Data used were those from D0, D20, D40 and D60. Significance: ${ }^{*} p<0.05,{ }^{* *} p<0.01,{ }^{* * *} p<0.001$. 

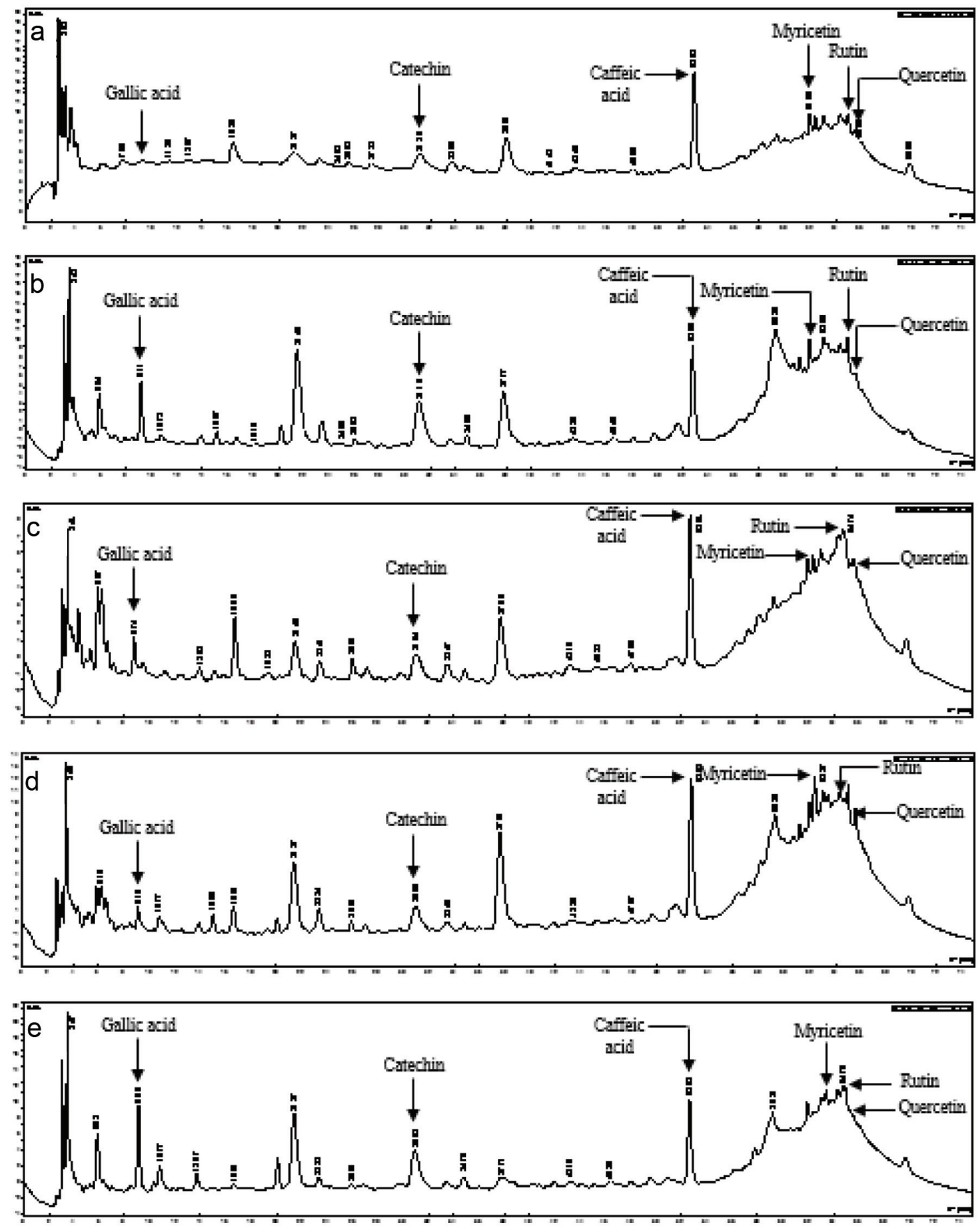

Figure 2. Chromatograms of polyphenolics compounds from Ocimum gratissimum produced with D0 (a), D20 (b), D40 (c), D60 (d) and D80 (e) and collected at first harvesting time.

$\mathrm{mg} / \mathrm{mL}$ ). Significant main factors (fertilizer micro-dose or harvest time) and interaction effects (Table 1$)$ were evidenced on $\mathrm{EC}_{50}$, respectively for $\mathrm{AC}(\mathrm{p}=0.04, \mathrm{p}=0.00$ and $\mathrm{p}=0.01), \mathrm{OG}(\mathrm{p}=0.00)$ and $\mathrm{SM}(\mathrm{p}=0.02, \mathrm{p}=0.00$ and $\mathrm{p}=0.00)$. Thus, values of $\mathrm{EC}_{50}$ were fertilizer micro-dose and harvest time-dependent (Figures $3 a$, $\mathrm{b}$ and $\mathrm{c})$ : the lowest $\mathrm{EC}_{50}$ was obtained from $\mathrm{D} 40 \mathrm{H} 1$ of $\mathrm{AC}(0.6$ $\mathrm{mg} / \mathrm{mL})$, D0H1 of OG $(0.2 \mathrm{mg} / \mathrm{mL})$ and D0H2 of SM $(0.1 \mathrm{mg} /$ $\mathrm{mL}$ ). The highest $\mathrm{EC}_{50}$ were found with application of $\mathrm{D} 40$ to $\mathrm{AC}$ (Figure 3a) at third harvest (D40H3: $1.2 \mathrm{mg} / \mathrm{mL}$ ), and with use of D0 for OG (Figure 3b) at third harvest (D0H3: $0.4 \mathrm{mg} / \mathrm{mL}$ ) and for 
a

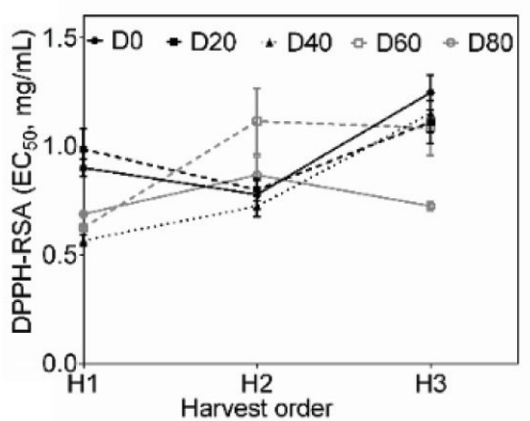

d

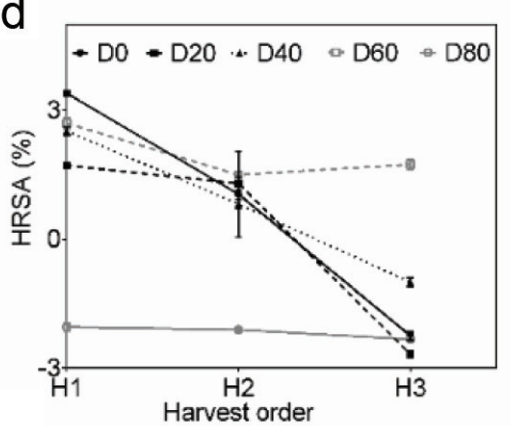

g

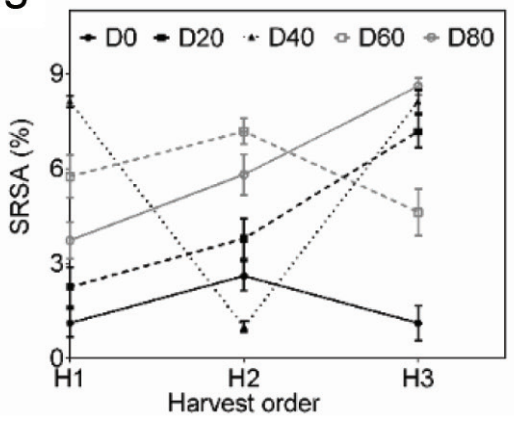

b

O. gratissimum

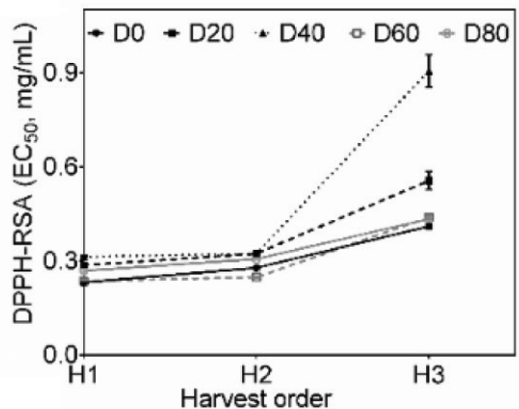

e

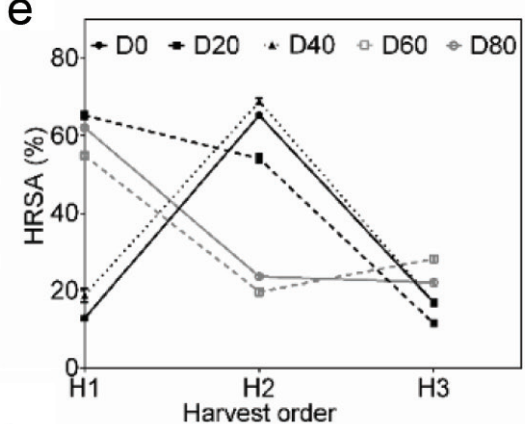

h

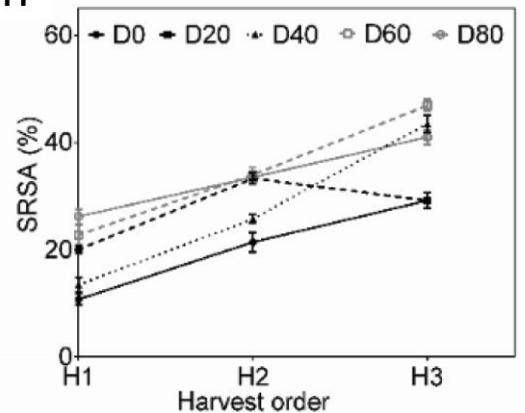

C S. macrocarpon

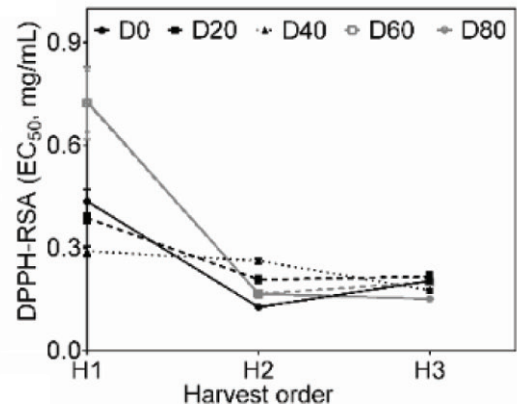

f

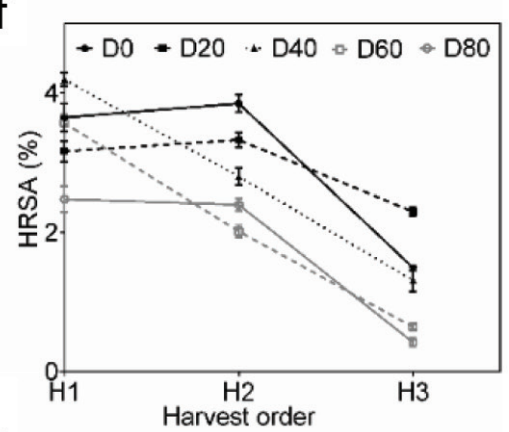

i

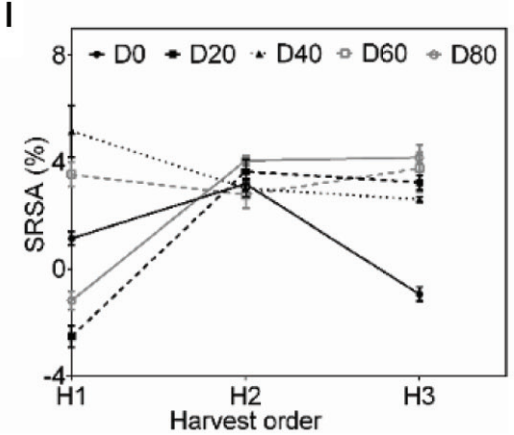

Figure 3. DPPH (a, b, c), hydroxyl (d, e, f) and superoxide (g, h, i) radical scavenging activities of polyphenol extracts from Amaranthus cruentus (a, d, g), Ocimum gratissimum (b, e, h) and Solanum macrocarpon (c, f, i).

SM (Figure 3c) at first harvest (D0H1: $0.4 \mathrm{mg} / \mathrm{mL}$ ).

\subsubsection{Hydroxyl radical scavenging activity (HRSA)}

The HRSA of aqueous extracts, ranged from -2.7 to $68.9 \%$ and were concentration-dependent: increasing with increase in aqueous extract concentrations. OG had higher HRSA (11.6-68.9\%) at 1.5 $\mathrm{mg} / \mathrm{mL}$ when compared to AC (-2.7-3.4\%) and SM (0.4-4.2\%) at $5.0 \mu \mathrm{g} / \mathrm{mL}$. Six samples from AC (D0H3, D20H3, D40H3, D80H1, D80H2 and D80H3) did not show any HRSA thus, samples of AC from application of D80 (regardless harvest time) and those from third harvest (regardless fertilizer micro-doses) were not considered for ANOVA. Values from AC were only affected by harvest time $(\mathrm{p}=0.01)$, decreasing with increasing in harvesting time (Table 1 and Figure $3 d$ ). Regarding OG and SM, significant main and interactive effects $(p=0.00)$ of fertilizer micro-dose and harvest time were evident (Table 1). The highest HRSA obtained with $\mathrm{D} 40 \mathrm{H} 2$ of $\mathrm{OG}(68.9 \%)$ and $\mathrm{D} 40 \mathrm{H} 1$ of SM $(4.2 \%)$ while the lowest HRSA for OG and SM produced with D40 were recorded at first $(18.9 \%)$ and third (1.3\%) harvests, respectively (Figures 3e and $\mathrm{f}$ ).

\subsubsection{Superoxide radical scavenging activity (SRSA)}

The SRSA of aqueous extracts ranged from 1.0 to $46.9 \%$. OG had higher SRSA $(10.7-46.9 \%)$ at $1.5 \mathrm{mg} / \mathrm{mL}$ when compared to AC (1.0-8.6\%) and SM (-2.5-5.2\%) at $5.0 \mu \mathrm{g} / \mathrm{mL}$. Three samples of SM (D0H3, D20H1 and D80H1) did not show any SRSA. ANOVA revealed significant main and interactive effects of fertilizer micro-dose and harvest time respectively for $\mathrm{AC}(\mathrm{p}=0.00$, $\mathrm{p}=0.01$ and $\mathrm{p}=0.00)$, OG $(\mathrm{p}=0.01, \mathrm{p}=0.00$ and $\mathrm{p}=0.00)$ and SM $(\mathrm{p}=0.00)$ at the highest concentrations tested (Table 1). Samples with the highest SRSA (Figures $3 \mathrm{~g}, \mathrm{~h}$ and i) were from $\mathrm{D} 80 \mathrm{H} 3$ for $\mathrm{AC}(8.6 \%), \mathrm{D} 60 \mathrm{H} 3$ for $\mathrm{OG}(46.9 \%)$ and $\mathrm{D} 40 \mathrm{H} 1$ for SM (5.2\%). However, application of D80 and D60 induced low SRSA at first harvest, respectively to AC (3.7\%) and OG $(22.8 \%)$. In contrast, the use of D40 for SM led to low SRSA at the third harvest $(2.6 \%)$. 
a

A. cruentus

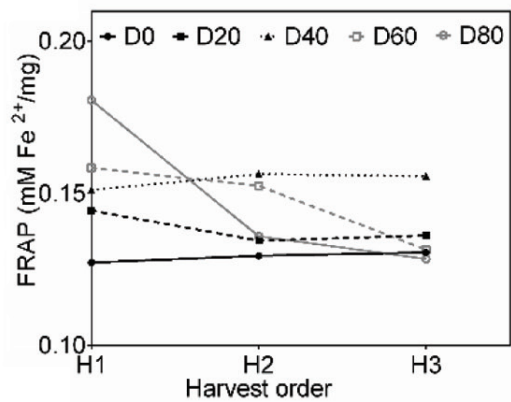

d

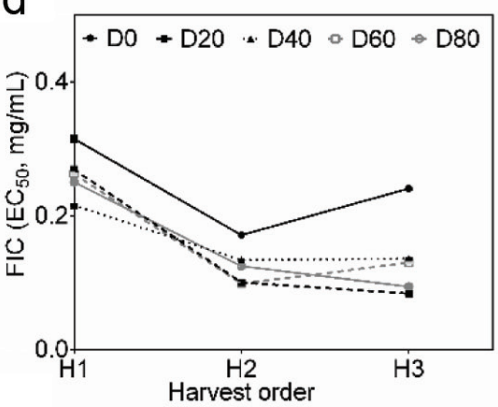

$g$

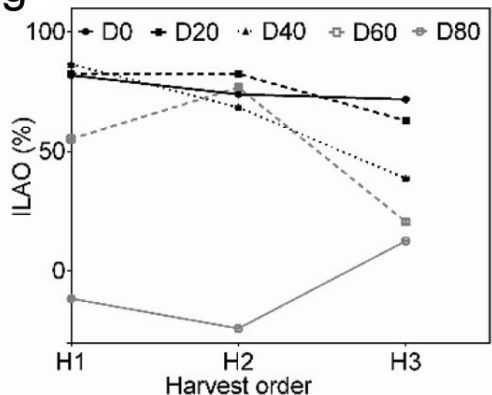

b

O. gratissimum

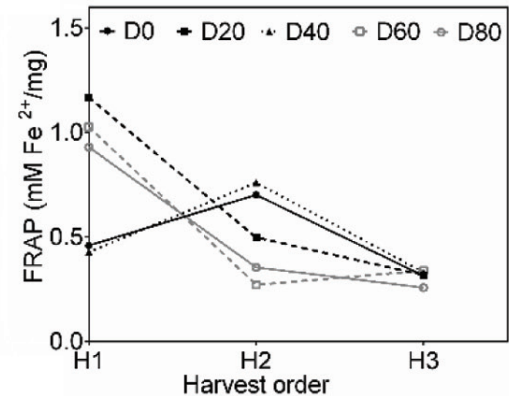

e

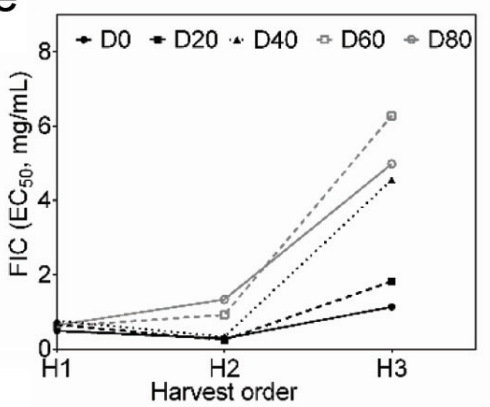

h

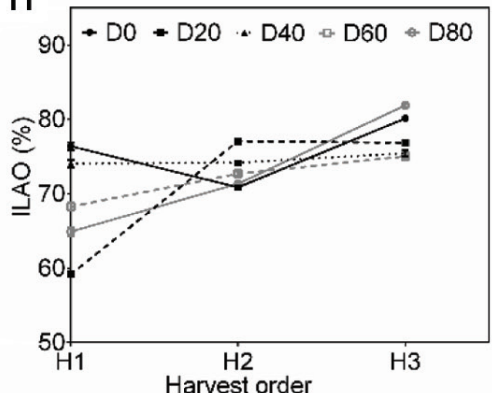

C

S. macrocarpon

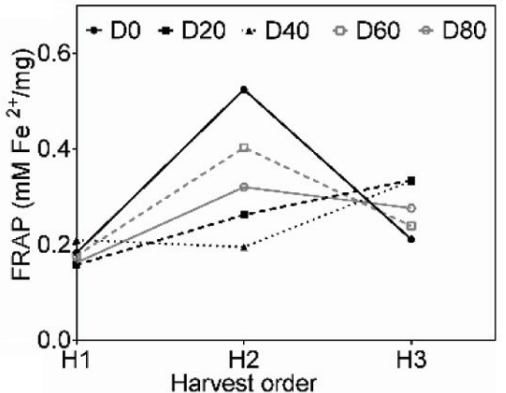

f

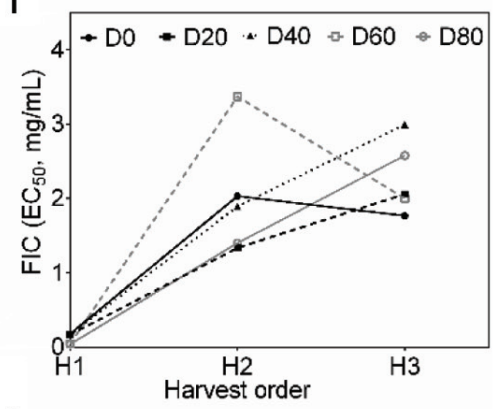

i

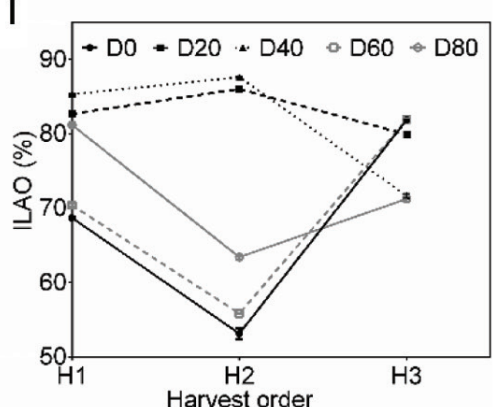

Figure 4. Ferric ion reducing power $(a, b, c)$ of, ferrous ions chelation $(d, e, f)$ and inhibition of linoleic acid oxidation (g, $h$, i) by polyphenol extracts from Amaranthus cruentus $(a, d, g)$, Ocimum gratissimum $(b, e, h)$ and Solanum macrocarpon $(c, f, i)$.

\subsubsection{Ferric ion reducing antioxidant power (FRAP)}

The FRAP of OG $\left(0.3-1.2 \mathrm{mM} \mathrm{Fe} \mathrm{F}^{2+} / \mathrm{mg}\right)$ and SM $(0.2-0.5 \mathrm{mM}$ $\left.\mathrm{Fe}^{2+} / \mathrm{mg}\right)$ were higher than those of all samples from $\mathrm{AC}(0.1-0.2$ $\left.\mathrm{mM} \mathrm{Fe}^{2+} / \mathrm{mg}\right)$. ANOVA indicated significant main and interactive effects $(p=0.00)$ of fertilizer micro-dose and harvest time for all vegetable species (Table 1$)$. Interaction of both factors revealed higher FRAP (Figures $4 \mathrm{a}, \mathrm{b}$ and c) with D80H1 for AC $(0.2 \mathrm{mM}$ $\left.\mathrm{Fe}^{2+} / \mathrm{mg}\right)$, D20H1 for OG $\left(1.2 \mathrm{mM} \mathrm{Fe} \mathrm{F}^{2+} / \mathrm{mg}\right)$ and D0H2 for SM $\left(0.5 \mathrm{mM} \mathrm{Fe}{ }^{2+} / \mathrm{mg}\right)$. Lower FRAP recorded with application of D80 to AC (Figure $4 \mathrm{a}$ ) and of D20 to OG (Figure $4 \mathrm{~b}$ ) were at third harvest $\left(0.1 \mathrm{mM} \mathrm{Fe}^{2+} / \mathrm{mg}\right.$ and $0.3 \mathrm{mM} \mathrm{Fe} e^{2+} / \mathrm{mg}$, respectively) whereas production of SM with D0 (Figure 4c) induced lower FRAP at first harvest $\left(0.2 \mathrm{mM} \mathrm{Fe}^{2+} / \mathrm{mg}\right)$.

\subsubsection{Ferrous ion chelation (FIC)}

The FIC EC $\mathrm{E}_{50}$ of polyphenolic extracts varied strongly for AC samples $(0.1-0.3 \mathrm{mg} / \mathrm{mL})$ in comparison to $\mathrm{OG}(0.7-1.4 \mathrm{mg} / \mathrm{mL})$ and SM $(0.0-3.4 \mathrm{mg} / \mathrm{mL})$ samples. Significant main and interactive effects of fertilizer micro-dose and harvest time $(p=0.00)$ were observed for AC, OG and SM (Table 1). Samples from D20H3 of $\mathrm{AC}(0.1 \mathrm{mg} / \mathrm{mL}), \mathrm{D} 20 \mathrm{H} 2$ of $\mathrm{OG}(0.2 \mathrm{mg} / \mathrm{mL})$ had the lowest $\mathrm{EC}_{50}$ (Figures 4d, e and f) while AC and OG grown with D20 had the highest values at first $(0.3 \mathrm{mg} / \mathrm{mL})$ and third $(1.8 \mathrm{mg} / \mathrm{mL})$ harvests, respectively (Figures $4 \mathrm{~d}$ and e). Regarding SM (Figure $4 \mathrm{f}$ ), the lowest $\mathrm{EC}_{50}$ was found with $\mathrm{D} 80 \mathrm{H} 1(<0.1 \mathrm{mg} / \mathrm{mL})$ and the highest value observed with application of D80 was at third harvest $(2.6 \mathrm{mg} / \mathrm{mL})$.

\subsubsection{Inhibition of linoleic acid oxidation (ILAO)}

The ILAO by polyphenolic extracts was concentration-dependent and decreased with increase in extract concentrations. Absorption intensities of blank for polyphenolic extracts reached their highest intensities (0.8) at fourth day of incubation while OG and SM had lower absorption intensities $(<0.4)$ than AC (Figure 5). High ILAO was observed on the fourth day for AC ( $-24.1-86.6 \%)$, OG $(59.2-81.9 \%)$ and SM (53.1-87.6\%). Given that two samples of $\mathrm{AC}(\mathrm{D} 80 \mathrm{H} 1$ and D80H2) did not show any ILAO over the incuba- 

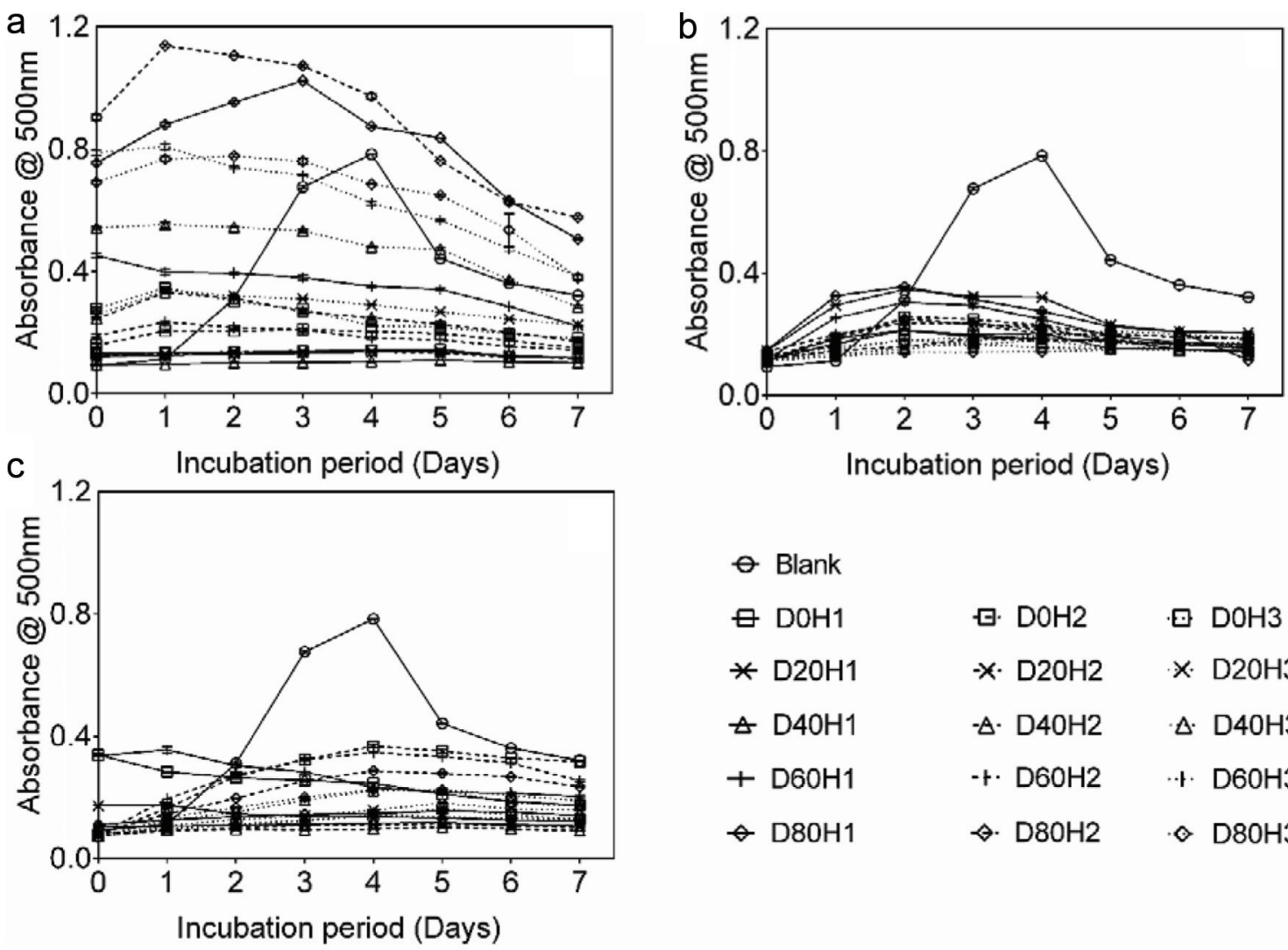

$\bullet \cdot \mathrm{DOH} 2$
$-\times \cdot \mathrm{D} 2 \mathrm{OH} 2$
$-\triangle \mathrm{D} 40 \mathrm{H}_{2}$
- - $\mathrm{D} 6 \mathrm{OH} 2$
$\diamond \cdot \mathrm{D} 8 \mathrm{OH} 2$

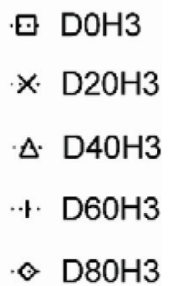

Figure 5. Inhibition of linoleic acid oxidation by polyphenol extracts from Amaranthus cruentus (a), Ocimum gratissimum (b) and Solanum macrocarpon (c) in comparison to blank.

tion time, samples of AC from D80 (regardless of harvest time) were discarded for ANOVA. There were significant main and interactive effects of fertilizer micro-dose and harvest time $(\mathrm{p}=0.00)$ for AC, $\mathrm{OG}$ and SM (Table 1). The highest ILAO were obtained (Figures $4 \mathrm{~g}$, h and i) with $\mathrm{D} 40 \mathrm{H} 1$ for $\mathrm{AC}(86.6 \%), \mathrm{D} 80 \mathrm{H} 3$ for OG $(81.9 \%)$ and D40H2 for SM (87.6\%) whereas the lowest ILAO was recorded with application of D40 to AC (38.7\%) and SM (71.6\%) at third harvest and with use of D80 to OG at first harvest (64.9\%).

\subsection{Relationship between polyphenolics and antioxidant activities}

Correlation between polyphenolic compounds and antioxidant activities (Table 2) revealed that TPC was significantly and positively correlated to content of some polyphenolics (catechin and quercetin) while negatively linked to others (myricetin). However, most of correlations found between polyphenolics and antioxidant activities were negative, except for TPC and DPPH-RSA ( $\mathrm{r}$ $=0.770, p=0.00)$, TFC and FIC $(r=0.533, p=0.00)$ as well as caffeic acid and SRSA $(r=0.578, p=0.00)$ or FIC $(r=0.632, p$ $=0.00$ ). Significant correlations were also recorded within antioxidant activities and the strongest was between HRSA and FRAP $(\mathrm{r}=0.878, \mathrm{p}=0.00)$. Linear regression revealed that increase in TPC enhanced $\mathrm{EC}_{50}$ values of DPPH-RSA and that TPC explained $59.3 \%$ of the variability observed for $\mathrm{EC}_{50}$ values of DPPH-RSA (Figure 6a). Similarly positive relation linked HRSA and FRAP, with $77.1 \%$ of the total variation explained (Figure $6 \mathrm{~b}$ ).

\section{Discussion}

\subsection{Polyphenols profile as affected by fertilizer micro-dose and harvest time}

Leafy vegetables produced with fertilizer micro-dosing had comparable range of polyphenolic compounds (caffeic acid, catechin, gallic acid myricetin, quercetin and rutin) to conventionally grown leafy vegetables. For example, gallic acid and rutin contents obtained in this study are similar to those reported by Oboh et al. (2016) in Amaranthus hybridus (1.3 mg/g), Talinium triangulare $(1.7 \mathrm{mg} / \mathrm{g}$ and $0.7 \mathrm{mg} / \mathrm{g}$, respectively), Telfairia occidentalis $(1.5$ $\mathrm{mg} / \mathrm{g}$ and $4.7 \mathrm{mg} / \mathrm{g}$, respectively) and Vernonia amygdalina $(0.5$ $\mathrm{mg} / \mathrm{g}$ and $1.6 \mathrm{mg} / \mathrm{g}$, respectively). Values of gallic acid contents are within the range of those reported in Mormodica charantia $(0.1-1.0 \mathrm{mg} / \mathrm{g})$ and Mormodica dioica and rutin $(0.3 \mathrm{mg} / \mathrm{g})$ in $M$. dioica (Nagarani et al., 2014). Caffeic acid and catechin contents found in this study for $\mathrm{AC}$ and $\mathrm{OG}$ are within the maximum and minimum values recorded in $M$. charantia $(0.1 \mathrm{mg} / \mathrm{g}$ and $1.5 \mathrm{mg} / \mathrm{g}$, respectively) and $T$. triangulare (3.0 and $0.7 \mathrm{mg} / \mathrm{g}$, respectively) (Nagarani et al., 2014; Oboh et al., 2016). The range of quercetin contents recorded for AC in this study is comparable to values reported (Nagarani et al., 2014; Oboh et al., 2016) for M. charantia $(26.0-41.9 \mathrm{mg} / \mathrm{g}), T$. triangulare $(2.5 \mathrm{mg} / \mathrm{g})$ and $V$. amygdalina (4.3 mg/g).

Fertilizer micro-dose, harvest time and interaction of both factors imparted various behaviours to the aqueous polyphenolic ex- 


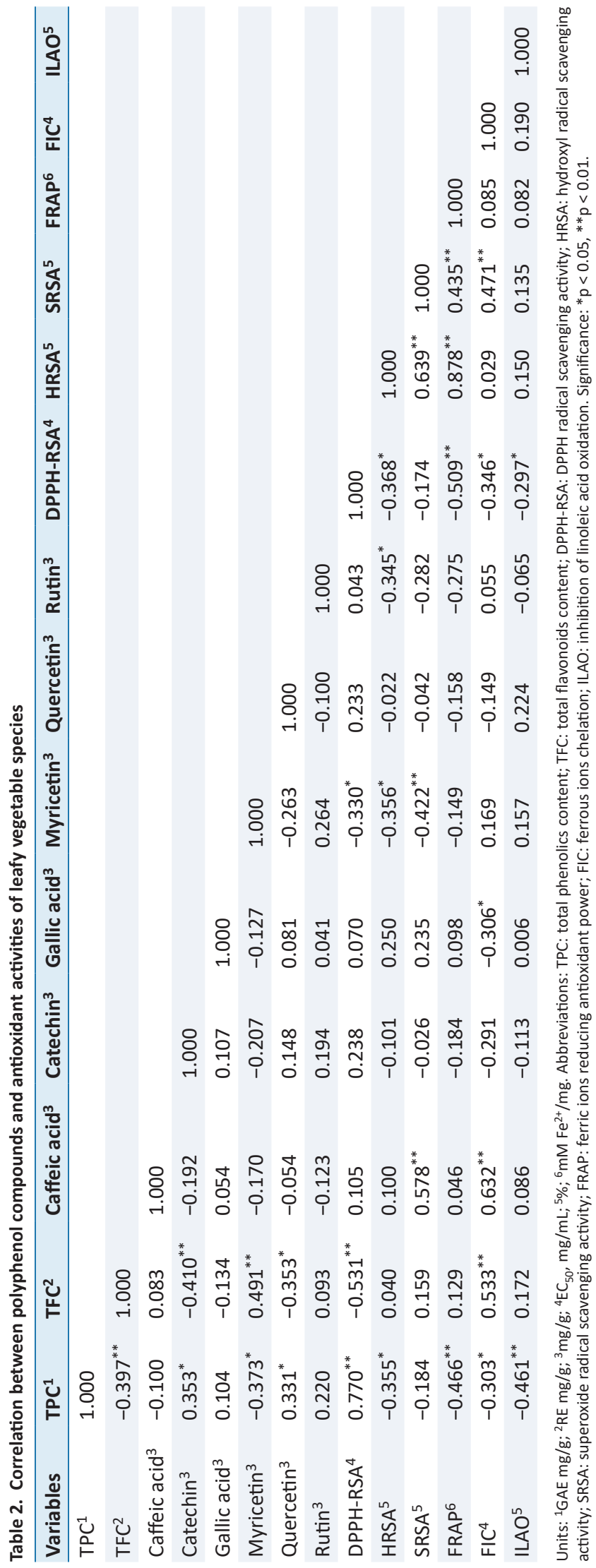

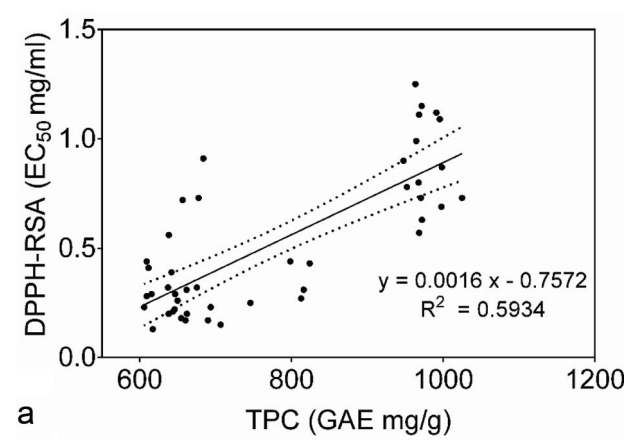

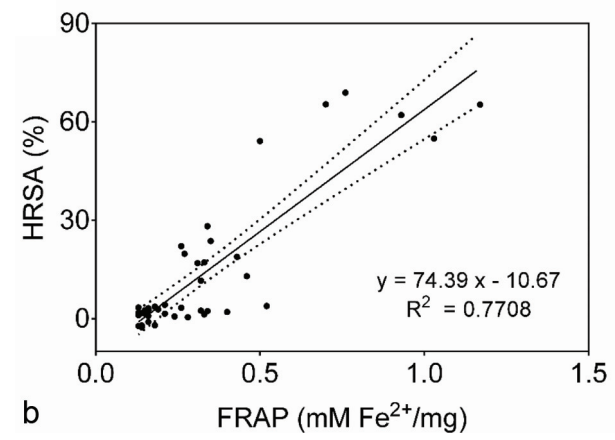

Figure 6. Relation between TPC and DPPH-RSA (a) and FRAP and HRSA (a).

tracts, which is in agreement with reports relating polyphenolic profile in leafy vegetables subjected to some agronomic and environmental factors including nutrient supply and harvest time (Brasileiro et al., 2015; Sossa-Vihotogbé et al., 2013a; Stefanelli et al., 2011; Tavarini et al., 2015). Uses of urea micro-doses and/or cattle manure were beneficial for polyphenolic compounds synthesis, which is consistent with reports on the effect of organic fertilizer associated with moderate doses of mineral fertilizer in promoting synthesis and availability of polyphenols within leafy vegetables (Sossa-Vihotogbé et al., 2013a). The results suggest a structurespecific response of polyphenol synthesis to doses of nitrogen fertilization. High nitrogen supplies have been reported to facilitate plant growth and photosynthesis, which was associated with enhanced synthesis of nitrogen-based compounds at the expense of carbon-based metabolites (e.g., polyphenols) that lack nitrogen within their chemical structure (Stefanelli et al., 2011; Tavarini et al., 2015). Synthesis of carbon-based metabolites is favored under limited nitrogen conditions via phenylpropanoid metabolism in the plant during which activity of phenylalanine ammonia-lyase, levels of ammonia and synthesis of phenolic compounds increased (Stefanelli et al., 2011). Likewise, organic farming has demonstrated its ability to increase soil capacity to store adequate moisture and nutrients used by the plant for synthesis of polyphenols (Ibrahim et al., 2011).

Nevertheless, synthesis of metabolites is related to a plant's particular needs during growth and differentiation processes, which are linked to maturity stage and environmental conditions (Tavarini et al., 2015). During their growth, one of plants' defense strategies to injury stress is to activate phenylpropanoid metabolism thereby, increasing synthesis of polyphenolic compounds, which protect leaves during their normal ontogeny (Brasileiro et al., 2015; Tavarini et al., 2015). Thus, the variability found in effect of fertilizer micro-dose, harvest time and interaction of both factors in this study could be related to type 
and rate of fertilizer supplied to the plant. The variability could also be due to differences in responses of plant species to environmental conditions (determining polyphenolic contents at first harvest) and to mechanical wounding caused by successive leaf harvests (influencing polyphenolic contents at the last two harvests).

\subsection{Variability in antioxidant activities as response of fertilizer dose and harvest time}

The in vitro screening methods used in this study were reported as appropriate methods for identification of potential antioxidant sources due to their relatively low-cost, easiness to perform, use of non-ultra-sensitive equipment and widespread application (de Camargo et al., 2019; Granato et al., 2018). The $\mathrm{EC}_{50}$ from DPPHRSA recorded were higher than those reported by Oboh et al. (2016) for A. hybridus $(36.4 \mu \mathrm{g} / \mathrm{mL})$, T. triangulare $(54.9 \mu \mathrm{g} / \mathrm{mL})$, T. occidentalis $(37.7 \mu \mathrm{g} / \mathrm{mL})$ and $V$. amygdalina $(29.6 \mu \mathrm{g} / \mathrm{mL})$. The HRSA values found in this study are lower than those obtained by Fasakin et al. (2011) for $V$. amygdalina and G. latifolium (> $80 \%$ at $1 \mathrm{mg} / \mathrm{mL})$ while higher HRSA values $\left(\mathrm{EC}_{50}: 45.4-76.6 \mu \mathrm{g} /\right.$ $\mathrm{mL}$ ) were reported for $A$. hybridus, T. triangulare, T. occidentalis and $V$. amygdalina (Oboh et al., 2016). The SRSA values observed for OG are comparable to the SRSA reported for $V$. amygdalina $(15-40 \%)$ and G. latifolium $(10-30 \%)$ at $1 \mathrm{mg} / \mathrm{mL}$ concentration (Fasakin et al., 2011) but higher than those of AC and SM. The FRAP ranges reported for Ceratotheca sesamoïdes (34.3-44.5 $\mu \mathrm{M}$ $\left.\mathrm{Fe}^{2+} / \mathrm{g}\right)$, Justicia tenella $\left(37.8-45.7 \mu \mathrm{M} \mathrm{Fe}{ }^{2+} / \mathrm{g}\right)$, Lactuca sativa (186.7-396.2 $\mu \mathrm{M} \mathrm{Fe}^{2+} / \mathrm{g}$ ) and Sesamum radiatum (32.0-37.2 $\mu \mathrm{M}$ $\mathrm{Fe}^{2+} / \mathrm{g}$ ) (Sossa-Vihotogbé et al., 2013b; Stefanelli et al., 2011) are lower than those obtained in this study. The extracts used in this study exhibited higher FIC than those of $V$. amygdalina (18-23\%) and G. latifolium (5-10\%) (Fasakin et al., 2011). The ILAO by antioxidant compounds is associated with their free radical scavenging or metal ion chelation activity (Fasakin et al., 2011; Oboh et al., 2016; Yehye et al., 2015). At earlier incubation days (days $0-1$ ), polyphenolic extracts did not show ILAO because of gradual generation of linoleic acid peroxyl radicals. Thereafter, an overall inhibitory activity was observed over the incubation period with highest inhibition levels against linoleic peroxyl radicals on the fourth day. Gradual decrease of inhibitory activities were reported (Fasakin et al., 2011; Yehye et al., 2015) and linked to decomposition of lipid peroxides into oxidation products (aldehydes and ketones).

Antioxidant activities of leaf extracts suggest that they are good sources of water-soluble polyphenolic compounds, which exert DPPH-RSA, HRSA, SRSA, FRAP, FIC and ILAO. The moderate antioxidant activities recorded in this study indicate that quantified polyphenolic compounds may not have sufficient ability to scavenge already formed free radicals and simultaneously delay synthesis of ROS precursors, regardless of the structure-activity relationships governing antioxidant activities of polyphenolic compounds. These relationships result from ability of polyphenolic compounds to be involved in redox reactions through the presence of aromatic rings, carboxyl, hydroxyl and/or methoxyl groups within their structures (Guerrero et al., 2012; Irondi et al., 2016; Mathew et al., 2015). Regarding phenolic acids, cinnamic acid derivatives (e.g., caffeic acid) have greater potency as hydrogen donors via $-\mathrm{CH}=\mathrm{CH}-\mathrm{COOH}$ group than benzoic acid derivatives (gallic acid) that possess carboxyl groups (Mathew et al., 2015). Superoxide radical can undergo Fenton reactions to generate more ROS including hydroxyl radicals (formed by interactions of metal ions with $\mathrm{H}_{2} \mathrm{O}_{2}$ ), which accelerate lipid peroxidation while FRAP measure the ability of antioxidants agents to reduce $\mathrm{Fe}^{3+}$ to $\mathrm{Fe}^{2+}$ (Fasakin et al., 2011; Yehye et al., 2015). Thus, FIC may afford protection against oxidative damage by preventing hydroxyl radical formation and lipid peroxidation. The higher HRSA, SRSA and FRAP by OG extracts and higher DPPH-RSA by SM extracts may account for their higher ILAO when compared to AC extracts. Consistently, high radical scavenging activity and inhibition of lipid peroxidation reported for $V$. amygdalina were related to synergistic effects of polyphenolics compounds that create a broad spectrum of antioxidant activities (Fasakin et al., 2011; Oboh et al., 2016). Furthermore, vitamins (non-phenolic compounds) were associated with DPPH-RSA, HRSA and FRAP of A. hybridus, T. triangulare, T. occidentalis and $V$. amygdalina extracts (Oboh et al., 2016), suggesting that non-phenolic compounds may also have contributed to the measured antioxidant activities. Therefore, identification and characterization of the active components within each vegetable species are necessary because different classes of secondary metabolites can exhibit varying synergistic or antagonistic antioxidant potency. In addition, further researches using advanced analysis methods such as chromatographic techniques, in vitro biological tests (cellular-based methods), simulated digestion and in vivo models (de Camargo et al., 2019; Granato et al., 2018) are needed to fully understand the antioxidant properties of the studied leaf extracts.

Antioxidant activities were significantly affected by fertilizer application, harvest time and their interaction, emphasizing importance of these factors in functional quality of leafy vegetables. The association between urea micro-dosing combined with cattle manure and one of the first two leaf harvests induced significantly higher antioxidant activities than urea or manure alone combined with third harvest. Thus, nitrogen micro-dosing associated with organic fertilizer for growth of leafy vegetables that will be harvested at early maturity stage could be considered as beneficial to synthesis and activity of water-soluble free radical-scavenging polyphenols. Significant decreases in DPPH-RSA and FRAP with increase of nitrogen application doses as well as increase in these antioxidant activities with co-application of mineral and organic fertilizers had also been previously reported (Olarewaju et al., 2018; Sossa-Vihotogbé et al., 2013b; Stefanelli et al., 2011). High level of antioxidant activities found at the first two harvests could be linked to fertilization (for the first harvest) and to injury stress caused by first leaf harvest (for the second harvest). Indeed, plant injury at leaf harvest is a form of stress that can increase synthesis of polyphenolic compounds as part of plant defense strategy and these compounds are well-known as free radical scavengers (Brasileiro et al., 2015; Tavarini et al., 2015). Soil impoverishment due to fertilization option chosen in this study (one week before transplanting for manure and immediately after transplanting for urea) may explain lower antioxidant activities observed at third harvest. Higher DPPH-RSA and FRAP by $J$. tenella fertilized with NPK and cattle manure were reported at second harvest while that of $C$. sesamoïdes and S. radiatum were at second and third harvest times (Sossa-Vihotogbé et al., 2013b).

\subsection{Correlation between polyphenolics and antioxidant activi- ties}

There were more significantly negative correlations found between TPC, TFC, identified polyphenolic compounds and antioxidant activities than positive ones, indicating that measured antioxidant activities may result from synergistic or antagonistic effects between ROS and polyphenolic (identified or not) or with non-phenolic compounds within the extracts (Nagarani et al., 2014; Oboh et al., 
2016). Otherwise, steric hindrance between carboxylate group and hydroxyl groups within structure of phenolic acids (e.g., hydroxybenzoic acids) as well as glycosylation of flavonoids (e.g., rutin) were negatively associated to free radical scavenging activities (Denardin et al., 2015). The negative correlations suggested that high contents of polyphenolic compounds may be harmful due to pro-oxidative effects or increased reaction with beneficial concentrations of ROS normally present at physiological conditions that are required for optimal cellular functioning (Bouayed and Bohn, 2010). Positive correlations found suggest that the measured antioxidant activities are promoted by similar sources of polyphenolic compounds, consistent with the report on positive correlation between phenolic content and radical scavenging activity of $L$. sativa (Viacava et al., 2014). Positive correlations found between TPC and catechin or quercetin contents were not expected but may be linked to structural changes within complex phenolic compounds due to conversion into hydrolysable forms, which increase reaction intensity with Folin Ciocalteu reagent (Djibril-Moussa et al., 2019). Given that low $\mathrm{EC}_{50}$ values indicate greater antioxidant activities, significantly negative correlations found between DPPHRSA and TFC or myricetin content as well as between FIC and TPC or gallic acid content suggest that flavonoids and phenolics were, respectively stronger contributor to DPPH-RSA and FIC in leafy vegetables. The structure-activity relationships between antioxidant activities explain the positive relations found between HRSA and SRSA or FRAP.

\section{Conclusion}

Leafy vegetables produced under fertilizer micro-dosing are potential sources of phytochemicals with nutraceuticals properties, which can be useful in management of oxidative stress-related disorders or to reduce negative effects of ROS on food quality. The variability in polyphenolics between vegetable species was strengthened by interaction of fertilizer micro-dose and harvest time resulting in synergistic or antagonistic antioxidant effects. Based on our finding, it is of critical importance to investigate effect of application of fertilizers after each harvest since the present work has shown loss of antioxidant activity after more than two leaf harvests while multiple harvests are necessary to increase farmers' income.

\section{Acknowledgments}

This work was supported by the International Development Research Centre (IDRC) and Global Affairs Canada, through the Canadian International Food Security Research Fund (CIFSRF) Project No. 107983 [IDRC Grant: 107983-003]. The authors thank graduate students and other colleagues who worked on the experimental field that produced the vegetables. We also greatly appreciate the technical assistance of Dennis Joseph and Dennis Labossiere of the Department of Food and Human Nutritional Sciences, University of Manitoba throughout the laboratory works.

\section{References}

Achigan-Dako, E.G., Pasquini, M.W., Assogba-Komlan, F., N'danikou, S., Yédomonhan, H., Dansi, A., and Ambrose-Oji, B. (2010). Traditional vegetables in Benin. Institut National des Recherches Agricoles du Bénin, Cotonou: Imprimeries du CENAP, p. 282.
Adams, A.M., Gillespie, A.W., Kar, G., Koala, S., Ouattara, B., Kimaro, A.A., Bationo, A., Akponikpe, P.B.I., Schoenau, J.J., and Peak, D. (2016). Long term effects of reduced fertilizer rates on millet yields and soil properties in the West-African Sahel. Nutr. Cycl. Agroecosys. 106: $17-29$.

Bindraban, P.S., Dimkpa, C., Nagarajan, L., Roy, A., and Rabbinge, R. (2015). Revisiting fertilizers and fertilisation strategies for improved nutrient uptake by plants. Biol. Fertil. Soils 51: 897-911.

Bouayed, J., and Bohn, T. (2010). Exogenous antioxidants-Double-edged swords in cellular redox state. Health beneficial effects at physiologic doses versus deleterious effects at high doses. Oxid. Med. Cell. Longev. 3: 228-237.

Brasileiro, B.G., Leite, J.P.V., Casali, V.W.D., Pizziolo, V.R., and Coelho, O.G.L. (2015). The influence of planting and harvesting times on the total phenolic content and antioxidant activity of Talinum triangulare (Jacq.) Willd. Acta Sci. 37: 249-255.

de Camargo, A.C., Biasoto, A.C.T., Schwember, A.R., Granato, D., Rasera, G.B., Franchin, M., Rosalen, P.L., Alencar, S.M., and Shahidi, F. (2019). Should we ban total phenolics and antioxidant screening methods? The link between antioxidant potential and activation of NF-KB using phenolic compounds from grape by-products. Food Chem. 290: 229-238.

Denardin, C.C., Hirsch, G.E., Rocha, R.F., Vizzotto, M., Henriques, A.T., Moreira, J.C.F., Guma, F.T.C.R., and Emanuelli, T. (2015). Antioxidant capacity and bioactive compounds of four Brazilian native fruits. J. Food Drug Anal. 23: 387-398.

Djibril Moussa, M.I., Alashi, A.M., Sossa-Vihotogbe, C.N.A., Akponikpe, P.B.I., Djenontin, A.J., Baco, M.N., Akissoé, N.H., and Aluko, R.E. (2019). Inhibition of renin-angiotensin system enzymes by leafy vegetables polyphenol extracts related to fertilizer micro-dosing and harvest time. Acta Hortic. 1238: 73-80.

Fasakin, C.F., Udenigwe, C.C., and Aluko, R.E. (2011). Antioxidant properties of chlorophyll-enriched and chlorophyll-depleted polyphenolic fractions from leaves of Vernonia amygdalina and Gongronema latifolium. Food Res. Int. 44: 2435-2441.

Granato, D., Shahidi, F., Wrolstad, R., Kilmartin, P., Melton, L.D., Hidalgo, F.J., Miyashita, K., van Camp, J., Alasalvar, C., Ismail, A.B., Elmore, S., Birch, G.G., Charalampopoulos, D., Astley, S.B., Pegg, R., Zhou, P., and Finglas, P. (2018). Antioxidant activity, total phenolics and flavonoids contents: Should we ban in vitro screening methods? Food Chem. 264: 471-475.

Guerrero, L., Castillo, J., Quiñones, M., Garcia-Vallvé, S., Arola, L., Pujadas, G., and Muguerza, B. (2012). Inhibition of angiotensin-I converting enzyme activity by flavonoids: Structure-activity relationship studies. PLOS ONE. 7: e49493.

Hui-Fang, C., You-Cheng, S., Kamesh, V., and Chin-Kun, W. (2018). Popular functional foods and nutraceuticals with lipid lowering activity and in relation to cardiovascular disease, dyslipidemia, and related complications: an overview. J. Food Bioact. 2: 16-27.

Houston, M.C. (2010). The role of cellular micronutrient analysis, nutraceuticals, vitamins, antioxidants and minerals in the prevention and treatment of hypertension and cardiovascular disease. Ther. Adv. Cardiovasc. Dis. 4: 165-183.

Ibrahim, M.H., Jaafar, H.Z.E., Rahmat, A., and Rahman, Z.A. (2011). Effects of nitrogen fertilization on synthesis of primary and secondary metabolites in three varieties of kacip fatimah (Labisia pumila Blume). Int. J. Mol. Sci. 12: 5238-5254.

Irondi, E.A., Agboola, S.O., Oboh, G., and Boligon, A.A. (2016). Inhibitory effect of leaves extracts of Ocimum basilicum and Ocimum gratissimum on two key enzymes involved in obesity and hypertension in vitro. J. Intercult. Ethnopharmacol. 5: 396-402.

Mathew, S., Abraham, T.E., and Zakaria, Z.A. (2015). Reactivity of phenolic compounds towards free radicals under in vitro conditions. J. Food Sci. Tech. 52: 5790-5798.

Nagarani, G., Abirami, A., and Siddhuraju, P.A. (2014). Comparative study on antioxidant potentials, inhibitory activities against key enzymes related to metabolic syndrome, and anti-inflammatory activity of leaf extract from different Momordica species. Food Sci. Hum. Wellness 3: $36-46$.

Oboh, G., Akinyemi, A.J., Adeleye, B., Oyeleye, S.I., Ogunsuyi, O.B., Ademosun, A.O., Ademiluyi, A.O., and Boligon, A.A. (2016). Polyphenolic 
compositions and in vitro angiotensin-I-converting enzyme inhibitory properties of common green leafy vegetables: A comparative study. Food Sci. Biotech. 25: 1243-1249.

Olarewaju, O.A., Alashi, A.M., Taiwo, K.A., Oyedele, D., Adebooye, O.C., and Aluko, R.E. (2018). Influence of nitrogen fertilizer micro-dosing on phenolic content, antioxidant, and anticholinesterase properties of aqueous extracts of three tropical leafy vegetables. J. Food Biochem. 42: e12566.

Sossa-Vihotogbé, C.N.A., Anihouvi, B.V., Akissoe, H.N., Amadji, L.G., and Hounhouigan, D.J. (2013a). Effect of organic and mineral fertilization on proximate composition of three leafy vegetables harvested at different periods. Int. J. Biol. Chem. Sci. 7: 271-286.

Sossa-Vihotogbé, C.N.A., Akissoe, N.H., Anihouvi, V.B., Ahohuendo, B.C., Ahanchede, A., and Hounhouigan, D.J. (2013b). Effect of fertilization and harvesting time on antioxidant activity of three leafy vegetables commonly used in Benin. Afr. J. Food Agric. Nutr. Dev. 13: 8293-8312.

Stefanelli, D., Winkler, S., and Jones, R. (2011). Reduced nitrogen availability during growth improves quality in red oak lettuce leaves by minimizing nitrate content, and increasing antioxidant capacity and leaf mineral content. Agric. Sci. 2: 477-486.
Tavarini, S., Sgherri, C., Ranieri, A.M., and Angelini, L.G. (2015). Effect of nitrogen fertilization and harvest time on steviol glycosides, flavonoid composition, and antioxidant properties in Stevia rebaudiana Bertoni. J. Agric. Food Chem. 63: 7041-7050.

Tovihoudji, P.G., Akponikpè, P.I., Adjogboto, A., Djenontin, J.A., Agbossou, E.K., and Bielders, C.L. (2018). Combining hill-placed manure and mineral fertilizer enhances maize productivity and profitability in northern Benin. Nutr. Cycl. Agroecosys. 110: 375-393.

Viacava, G.E., Gonzalez-Aguilar, G., and Roura, S.I. (2014). Determination of phytochemicals and antioxidant activity in butter head lettuce related to leaf age and position. J. Food Biochem. 38: 352-362.

Vodouhe, A., Dovoedo, A., Anihouvi, A.B., and Tossou, R.C. (2012). Influence du mode de cuisson sur la valeur nutritionnelle de Solanum macrocarpon, Amaranthus hybridus, et Ocimum gratissimum, trois légumes-feuilles traditionnels acclimatés au Bénin. Int. J. Biol. Chem. Sci. 6: 1926-1937.

Yehye, W.A., Abdul Rahman, N., Ariffin, A., Bee Abd Hamid, S., Alhadi, A.A., Kadir, F.A., and Yaeghoobi, M. (2015). Understanding the chemistry behind the antioxidant activities of butylated hydroxytoluene (BHT): A review. Eur. J. Med. Chem. 101: 295-312. 